\title{
Phytoprotection
}

\section{In vitro effect of marigold seed exudates on plant parasitic nematodes}

\section{Ekaterini Riga, Catharine Hooper et John Potter}

Volume 86, numéro 1, avril 2005

URI : https://id.erudit.org/iderudit/011712ar

DOI : https://doi.org/10.7202/011712ar

Aller au sommaire du numéro

Éditeur(s)

Société de protection des plantes du Québec (SPPQ)

ISSN

0031-9511 (imprimé)

1710-1603 (numérique)

Découvrir la revue

Citer cet article

Riga, E., Hooper, C. \& Potter, J. (2005). In vitro effect of marigold seed exudates on plant parasitic nematodes. Phytoprotection, 86(1), 31-35.

https://doi.org/10.7202/011712ar
Résumé de l'article

[Effet in vitro d'extraits liquides de graines de soucis sur des nématodes phytopathogènes]

La mortalité de Heterodera schachtii, Meloidogyne hapla, et de Pratylenchus penetrans causée par des extraits liquides obtenus à partir des graines de Tagetes erecta $\mathrm{cv}$. Crackerjack et de T. patula var. polynema était significativement $(P<0,05)$ plus grande que chez les témoins. Les extraits de graines contiennent des produits avec un effet nématicide. Des produits nématostatiques n'ont pas été trouvés dans les extraits. Deux fractions de chromatographie liquide à haute performance dérivées de $T$. erecta $\mathrm{cv}$. Crackerjack et une fraction dérivée de T. patula var. polynema ont causé la plus grande mortalité de $H$. schachtii en comparaison des témoins et du reste des fractions. 


\title{
In vitro effect of marigold seed exudates on plant parasitic nematodes
}

\author{
Ekaterini Riga', Catharine Hooper ${ }^{2}$, and John Potter ${ }^{3}$
}

Received 2004-10-12; accepted 2005-04-05

PHYTOPROTECTION 86 : $31-35$

\begin{abstract}
Water extracts from seed exudates of Tagetes erecta cv. Crackerjack and T. patula var. polynema caused significantly higher mortality $(P<0.05)$ to Heterodera schachtii, Meloidogyne hapla and Pratylenchus penetrans than the control extracts from radish, tomato and corn seeds, respectively. Marigold seed exudates consist of nematicidal compounds. Nematostatic compounds have not been found in the seed exudates. Two high-performance liquid chromatography fractions derived from $T$. erecta cv. Crackerjack and one from $T$. patula var. polynema caused the highest mortality of $H$. schachtii in comparison with a water control and the rest of the fractions.
\end{abstract}

Keywords: Nematicidal compounds, Tagetes erecta, Tagetes patula.

\section{[Effet in vitro d'extraits liquides de graines de soucis sur des nématodes phytopathogènes]}

La mortalité de Heterodera schachtii, de Meloidogyne hapla, et de Pratylenchus penetrans causée par des extraits liquides obtenus à partir des graines de Tagetes erecta cv. Crackerjack et de T. patula var. polynema était significativement $(P<0,05)$ plus grande que chez les témoins. Les extraits de graines contiennent des produits avec un effet nématicide. Des produits nématostatiques n'ont pas été trouvés dans les extraits. Deux fractions de chromatographie liquide à haute performance dérivées de T. erecta cv. Crackerjack et une fraction dérivée de T. patula var. polynema ont causé la plus grande mortalité de $H$. schachtii en comparaison des témoins et du reste des fractions.

Mots clés: Tagetes erecta, Tagetes patula, composés nématicides.

Plant-parasitic nematodes are cosmopolitan parasites of many crops worldwide and are responsible for losses of 10 to $50 \%$ within a single crop yield (Barker et al. 1998). The sugar beet cyst nematode, Heterodera schachtii Schmidt, occurs in many parts of the world including Canada and the US (Baldwin and Mundo-Ocampo 1991). This nematode infects numerous cruciferous plants including sugar beet, Beta vulgaris L. Up to $90 \%$ of damage to sugar beets has been reported as a result of infection with $H$. schachtii (Steele 1984). The root-knot nematode, Meloidogyne hapla Chitwood, and the lesion nematode, Pratylenchus penetrans Cobb, occur in temperate regions, infect a wide range of plants worldwide, and cause varying degrees of economic losses (Barker et al. 1998; Loof 1991). Until recently, control of these nematodes was achieved by synthetic nematicides, some of which are environmentally undesirable (Dunn and Noling 1997). Recently, the need for novel plant-derived nematicides that are non-persistent, biodegradable and non-toxic to nontarget organisms has been increasing.
Marigold, Tagetes spp., has been known to produce nematicidal compounds (Kimpinski et al. 2000; Ploeg 1999; Sipes and Arakaki 1997). One of the main marigold compounds with nematicidal properties is a thiophene photoactivated compound called $\propto$-terthienyl (Bakker et al. 1979; Hasan 1992).

The effect of marigold seed exudates on nematodes has not been investigated. The purpose of this project was to investigate the nematicidal properties of marigold seed exudates and to identify potential sources that will lead to novel nematicidal plantderived compounds.

Seeds of T. patula L. (var. polynema) and T. erecta L. (cv. Crackerjack) (Stokes Seeds Ltd., St. Catharines, ON, Canada) (0.2 g each) were washed and wrapped in a nylon-permeable filter and placed in individual $6-\mathrm{cm}$ diam Petri dishes filled with $10 \mathrm{~mL}$ dechlorinated tap water for $72 \mathrm{~h}$ at $25^{\circ} \mathrm{C}$. Seeds of radish, Raphanus sativus L., corn, Zea mays L., and tomato, Lycopersicon esculentum Mill., were used as controls for $H$. schachtii, $P$. penetrans and $M$. hapla, respectively. At the end of the incubation period, 20 juveniles of each of $H$. schachtii, P. penetrans and $M$. hapla

1. Washington State University, IAREC, Prosser, WA, 99350, USA; corresponding author e-mail: riga@wsu.edu

2. Department of Biological Sciences, Brock University, St. Catharines, ON, Canada L2S 3A1

3. Agriculture \& Agri-Food Canada, 4902 Victoria Av. North, Vineland Station, ON, Canada LOR 2E0 


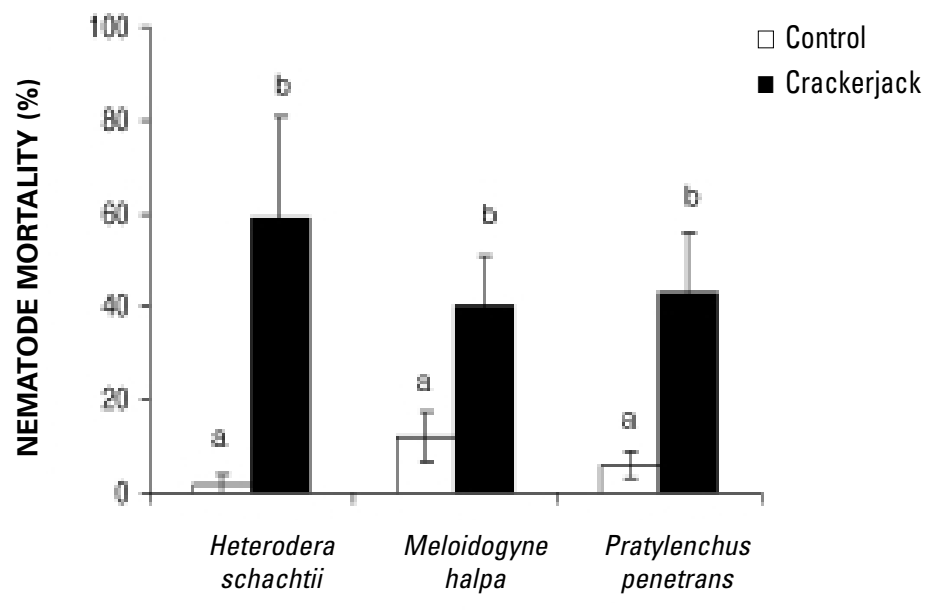

NEMATODE SPECIES

Figure 1a. The effect of water extract from seed exudates of Tagetes erecta (cv. Crackerjack), and radish, corn, and tomato controls on three species of plant-parasitic nematodes. Data for each column are averages \pm standard deviations of 30 replications. The same letter between treatments and control indicates no difference at $P<0.05$.

were added to each marigold seed exudates and control and incubated for $48 \mathrm{~h}$. Nematode mortality rates were assessed using a compound microscope after $48 \mathrm{~h}$. Nematodes that did not respond to physical probing using a metal probe were considered either dead or paralyzed. To determine whether marigold seed exudates were nematicidal (i.e. nematodes are dead) or nematostatic (i.e. nematodes are temporarily paralyzed), 20 nematodes that were incubated for $48 \mathrm{~h}$ in exudates were transferred to $5 \mathrm{~mL}$ dechlorinated tap water at $25^{\circ} \mathrm{C}$ for $24 \mathrm{~h}$. The nematodes were then observed under a compound microscope for signs of recovery and nematode mortality. Ten Petri dishes were used per exudate from either marigold or control for each nematode species. All assays were repeated three times.

Exudates from marigold seeds that were incubated in dechlorinated tap water for $72 \mathrm{~h}$ were collected, filtered using filter paper (\#5 qualitative filter paper, Whatman International Ltd., England) and placed into 200-mL scintillation vials. Each set of exudates was analyzed using a Hewlett Packard 1090 high-performance liquid chromatography (HPLC) apparatus with a U.V. detector (Hewlett-Packard, Waldbronn, Germany), and a DuPont Zorbax PSM 60 6.22X 250 column (Wilmington, DE, USA) at $40^{\circ} \mathrm{C}$. The solvents used

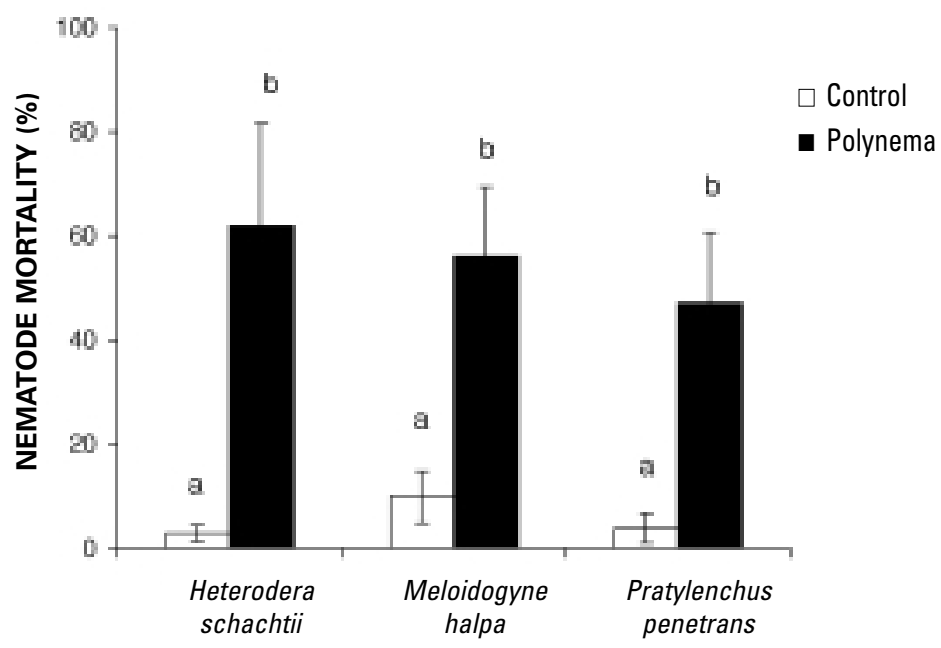

NEMATODE SPECIES

Figure 1b. The effect of water extract from seed exudates of $T$. patula (var. polynema), and radish, corn, and tomato controls on three species of plant-parasitic nematodes. Data for each column are averages \pm standard deviations of 30 replications. The same letter between treatments and control indicates no difference at $P<0.05$. 


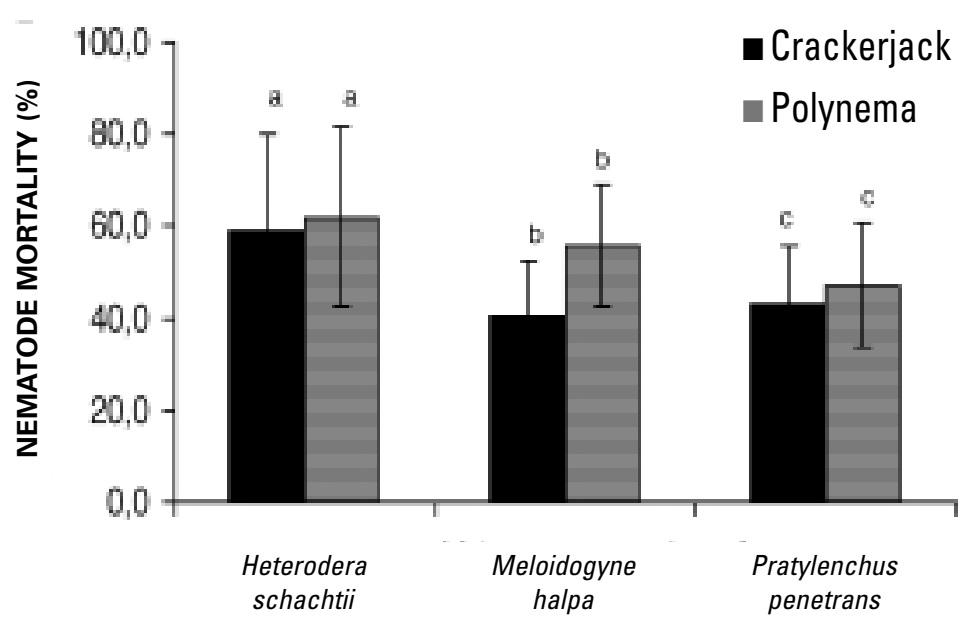

NEMATODE SPECIES

Figure 1c. The effect of water extract from seed exudates of $T$. patula (var. polynema) and $T$. erecta (cv. Crackerjack) on three species of plant-parasitic nematodes. Data for each column are averages \pm standard deviations of 30 replications. The same letter between treatments of the same species indicates no difference at $P<0.05$.

were acetonitrile and tap water that had been prepared using millipore filtration. Exudates of each marigold variety $(250 \mu \mathrm{L})$ were injected into the column at a flow rate of $1 \mathrm{~mL} \mathrm{~min}^{-1}$ and each HPLC run lasted for $20 \mathrm{~min}$. Four runs per sample were performed. Dechlorinated tap water was used as control. The derived fractions were collected and $250 \mu \mathrm{L}$ of each fraction was added to a microcavity slide (16 $\mathrm{mm} \times 3 \mathrm{~mm}$ ) (Clay Adams, New York, USA) with 20 $H$. schachtii juveniles. The slides were sealed to prevent evaporation and incubated for $72 \mathrm{~h}$ at $25^{\circ} \mathrm{C}$, after which recovery and nematode mortality rates were assessed. For control treatment, nematodes were put in a slide containing water. Due to the limited HPLC fraction quantities extracted from marigold seeds, only $H$. schachtii was tested in the consecutive assays since this nematode appeared more sensitive to the effects of marigold seed exudates. HPLC fractionation of marigold seed extracts and nematode assays were repeated three times. Data from the three repetitions were combined. Prior to statistical analysis, the combined data were tested for homogeneity of variances (Devore 1987). Statistical differences $(P<0.05)$ were tested using the Kruskal-Wallis test and Tukey's multiple comparisons method (Devore 1987) among exudates for each nematode in the mortality assays and among the HPLC fractions for each marigold species.

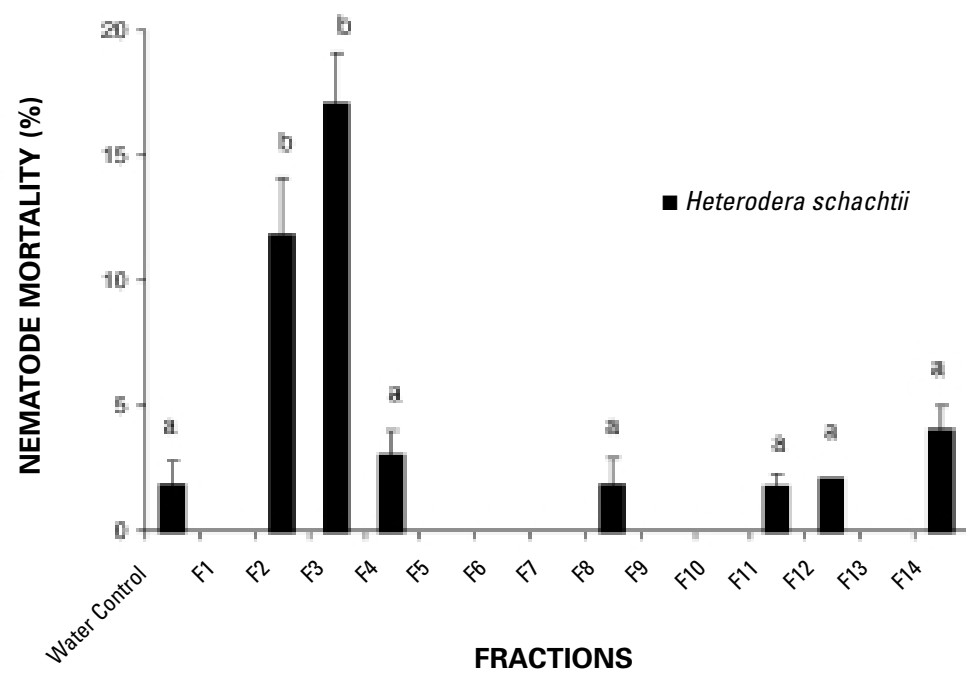

Figure 2. The effect of HPLC fractions derived from water extract from seed exudates of Tagetes erecta (cv. Crackerjack) and water control on Heterodera schachtii. Data for each column are averages \pm standard deviations of 3 replications. The same letter between treatments indicates no difference at $P<0.05$. 


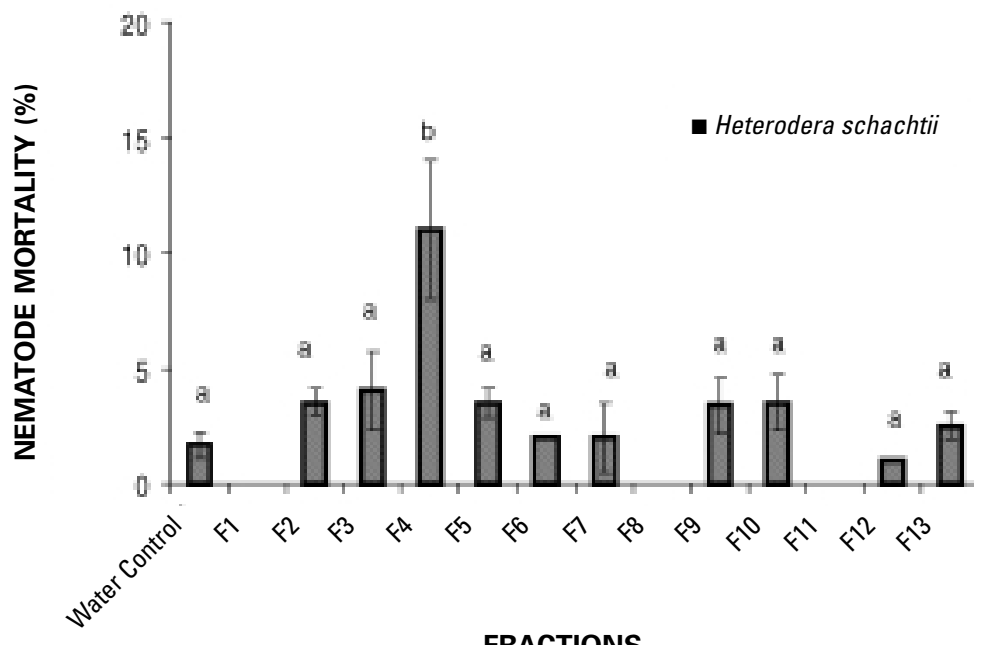

FRACTIONS

Figure 3. The effect of HPLC fractions derived from water extract from seed exudates of Tagetes patula (var. polynema) and water control on Heterodera schachtii. Data for each column are averages \pm standard deviations of 3 replications. The same letter between treatments indicates no difference at $P<0.05$.

Seed exudates of T. erecta (cv. Crackerjack) and T. patula (var. polynema) caused significantly higher mortality to $H$. schachtii, $M$. hapla and $P$. penetrans than did their respective controls $(P<0.05)$ (Fig. 1a and $1 \mathrm{~b}$ ). There was no significant difference between the mortality rates caused by the two marigold varieties. In addition, there was no significant difference between the mortality rates caused by each of the marigold seed extracts in each individual nematode species (Fig. 1c), although the trend suggests that T. patula (var. polynema) caused the highest mortality to $H$. schachtii. No significant nematode recovery was observed in comparison with the controls when the nematodes were transferred from the marigold seed exudates to water for $24 \mathrm{~h}$ (data not shown).

The HPLC fractions F2 and F3, derived from T. erecta, caused the highest mortality to $H$. schachtii juveniles in comparison with the water control and the rest of the fractions (Fig. 2). HPLC fraction F4, derived from $T$. patula, caused significantly $(P<0.05)$ higher mortality to $H$. schachtii juveniles than the control and the rest of the HPLC fractions (Fig. 3). No nematode recovery was observed in comparison with the control when nematodes were transferred from HPLC fractions to water for $24 \mathrm{~h}$ (data not shown).

Seed exudates from both Tagetes erecta (cv. Crackerjack) and T. patula (var. polynema) caused significantly higher mortality to $H$. schachtii, M. hapla and $P$. penetrans compared with control exudates from radish, corn and tomato seeds. Several reports exist on the nematicidal properties of marigolds from different parts of the plant (Alexander and Waldenmaier 2002; Kimpinski et al. 2000; Ploeg 1999; Siddiqui and Alam 1988). However, the nematicidal properties of marigold seed exudates in the laboratory or field have not been thoroughly investigated. Two HPLC fractions derived from $T$. erecta cv. Crackerjack and one fraction from $T$. patula var. polynema caused the highest $H$. schachtii mortality in comparison with the water control and the rest of the
HPLC fractions. Our study shows that seed exudates contain nematicidal compounds. No nematostatic compounds were found in these exudates since nematode recovery was not observed.

Additional work is needed to isolate and characterize compounds derived from marigold seed exudate fractions. Identifying new compounds may potentially lead to the discovery of novel plantderived nematicides.

\section{ACKNOWLEDGEMENTS}

The authors sincerely thank Dr. Richard Larsen, USDA-ARS, WA, for reviewing the manuscript.

\section{REFERENCES}

Alexander, S.A., and C.M. Waldenmaier. 2002. Suppression of Pratylenchus penetrans populations in potato and tomato using African marigolds. J. Nematol. 34 : 130134.

Bakker, J., F.J. Gommers, I. Niewenhuis, and H. Wynberg. 1979. Photoactivation of the nematicidal compound alpha-terthienyl from roots of marigolds (Tagetes species): A possible singlet oxygen role. J. Biol. Chem. 254 : 1841-1844.

Baldwin, J.G., and M. Mundo-Ocampo. 1991. Heteroderinae, cyst and non-cyst forming nematodes. Pages 275-362 in W.R. Nickle (ed.), Manual of agricultural nematology. Marcel Dekker Inc., New York.

Barker, K.R., G.A. Pederson, and G.L. Windham. 1998. Plant and nematode interactions. Vol. 36. American Society of Agronomy Inc., Madison, WI. 771 pp.

Devore, J.L. (ed). 1987. Probability and statistics for engineering and sciences. $2^{\text {nd }}$ Ed. Brooks/Cole Publishing Company, Monterey, CA.

Dunn, R., and J.W. Noling. 1997. Characteristics of principal nematicides. University of Florida. Gainesville, FL. Fact Sheet RF-NG009. IFAS Extension. http://edis.ifas.ufl.edu/BODY_NG009. 
Hasan, A. 1992. Allelopathy in the management of root knot nematodes. Pages 413-441 in S.J.H. Rizvi and V. Rizvi (eds.), Allelopathy: Basic and applied aspects. Chapman and Hall, London, UK.

Kimpinski, J., W.J., Arsenault, C.E., Gallant, and J.B. Sanderson. 2000. The effect of marigolds (Tagetes spp.) and other cover crops on Pratylenchus penetrans and on following potato crops. J. Nematol. 32 : 531-536.

Loof, P.A.A. 1991. The family Pratylenchidae Thorne, 1949. Pages 363-421 in W.R. Nickle (ed.), Manual of agricultural nematology. Marcel Dekker Inc., New York.

Ploeg, A.T. 1999. Greenhouse studies on the effect of marigolds (Tagetes spp.) on four Meloidogyne species. J. Nematol. $31: 62-69$.

Siddiqui, M.A, and M.M., Alam. 1988. Toxicity of different plant parts of Tagetes lucida to plant parasitic nematodes. Indian J. Nematol. $18:$ 181-185.

Sipes, B.S., and A.S. Arakaki. 1997. Root-knot nematode management in dryland taro with tropical cover crops. J. Nematol. 29 : (Suppl.) 721-724.

Steele, A.E. 1984. Nematode parasites of sugar beets. Pages 507-569 in W.R. Nickle (ed.), Plant and insect nematodes. Marcel Dekker Inc., New York. 